\title{
The Effect of Achievements of Bureaucracy Reformation to Performance Evaluation: Empirical Study from Indonesia's Local Government on the Indicator Basis for Period 2010-2014
}

\section{Marsdenia}

Department of Accounting, Vocational Program, Universitas Indonesia, Depok, Indonesia

\section{Abstract}

The purpose of this study is to analyze the effect of achievements of bureaucracy reformation to performance evaluation. Main contribution of this research is a new approach to measure local government performance evaluation. This study uses data from Indonesia's internal affair ministry, and from statistical bureau and other

Corresponding Author:

Marsdenia

idelid53@gmail.com

Received: 8 June 2018

Accepted: 17 July 2018

Published: 8 August 2018

Publishing services provided by Knowledge $\mathrm{E}$

(c) Marsdenia. This article is distributed under the terms of the Creative Commons

Attribution License, which permits unrestricted use and redistribution provided that the original author and source are credited.

Selection and Peer-review under the responsibility of the 2 nd ICVHE Conference Committee.

\section{G OPEN ACCESS} valid sources of data. Processing of data collected by regression model consists of simple and multivariate. This Research finding will be the Effect of achievements of bureaucracy reformation to performance evaluation: Empirical Study from Indonesia's Local Government on the indicator basis for period 2010-2014. The implication of this research will give an input to government whether it has a benefit to produce the indicator basis of achievement of reformation of bureaucracy.

Keywords: performance evaluation, reformation of bureaucracy, local government, indicator basis

\section{Introduction}

Bureaucracy reformation in Indonesia have been main issue since reformation action earlier 1997 and as moment of paradigm change of Indonesian history (Suwatin, 2010). Bureaucracy reformation implementation in Indonesia it is not easy, due to just not only about efficiency and effectivity, corruption is a big obstacles of government organization to show high performance in front of the public. Bureaucracy Reform is a national program consists of three pillars; organization structure and design, business processes, and human resources. Since government is a huge complex system with hierarchy, formal and rigid rules, therefore to succeed the reform, it must be executed gradually but systematically, consistently, and seriously (Effendi, 2009). Recently, public more aware about accountability of government, so government should maintain 
transparency to public in the form of reporting non-finance or non-finance indicator of performance. Well managed country hopefully have effect to society welfare, we expected well managed will cause reducing of agency cost in the level of government or country. According to OECD, good governance of government have a uniqueness that private sector doesn't have such as democracy element, which is give room of participation of society in the development and also transparency in the planning of government.

According to UU No. 25 of year 2004, Sesuai dengan amanat UU No. 25 tahun 2004, about national development planning system and ministry of internal affair rule No. 54 year of 2010 about PP no. 8 year of 2008 about stage of compilation, controlling and evaluation of implementation of local government development planning. Michael Troy (2002) finds local government performance evaluation is very crucial to keep local government on the track and comply to accountability principle and able to account for.

Prior research said it a must government should accountable, consistent, according to World Bank (1996) findings public participation as a one main principles to have a good corporate governance of public sector entity as a form of public participation in the development. The stakeholder interdependence to influence and share control and initiative of development, decision and resources for people wealth.

According to Ministry of Internal affair, local government performance evaluation by EKPPD Score, which is published by internal affair ministry by year. EKPPD measurement source of data from local government performance report (LKPD). Meanwhile, Mahmudi (2010) concluded that local government by autonomous right will have consequence to have responsibility to held government, and will evaluate the performance likely several basis, such as PAD, economic growth, poor score, IPM Local government development index).

\section{Hypothese Development}

\subsection{Indeks Pembangunan Manusia (IPM)}

IPM describes how population have accessed to the result of development in term of revenue, health, education and so on. IPM introduced by United Nations Development Programme (UNDP) in 1990 and published periodically in the annual report of Human Development Report (HDR). IPM formed by 3 (three) basic dimension: long live and healthy life, knowledge about feasible life. IPM is an indicator to measure the success in order to develop quality of human life (society/people). IPM can determined rank or level of country/district development. Meanwhile, for our country, Indonesia, IPM 
as strategic data because it will be a measurement of government performance, IPM also used to be one of governmental performance proxy, IPM also be one of allocator to determined general fund allocator. Currently (since 2014) IPM methodology have changed, the main reason for the changing are: Firstly, some of indicators did not proper any more for IPM calculations. Score of reading notes irrelevant to measure education in term of comprehensive due to its inability to describe current quality of education. Additionally, score of ability to read for each of local of government relatively high, so we cannot make discriminate level of education between county/local government. PDB per capita cannot describe the people real income of per country. secondly, arithmetic mean formula in IPM calculation describe that low achievement in certain local government can be offset by high achievement from other dimensions. Some indicators are: Score to read in the former method have changed as score expected length of education. Product Domestic Brutto (PDB) per capita changed as Product National Brutto (PNB). Aggregations Method have changed from arithmetic to geometric approach. The advantages of using IPM New Method because it used more proper indicator and better discriminate. By entry average length of study and score opportunity length of study, we can catch up relevant description about education and any probability of change. PNB replace PDB because more informative about public revenue at the specific area. By using geometric average of IPM compilation, it explained that achievement on one dimension cannot covered by another dimension achievement. It means, to implemented human building, those three dimensions should got same attention because have the same priority.

\subsection{Hypotheses development}

Baes and prior explanation and prior research, start from local government performance and Human development index (IPM), this research proposed the following hypotheses:

$\mathbf{H}_{1}$ : local government performance and Human development index (IPM)

\section{Researh Method}

\subsection{Data and sample}

This research used secondary data about local government in Java island, source of data from various valid resources, such as ministry internal affair, Center of statistic Bureau and local government websites. Population of this research for period 20102014. Table 3.1 description of the criteria of sample selection, population total is 
amounting to 435 and deducted by local government outside Java Island, the sample amounting to 212 with 424 firm years. The main reason sample only from Java Island because of Java Island as central of education, industry, technology and also central of population of Indonesia. The other reason is data collected from internet, as we know Java Island central of growth so this is in line with reason the research sample only local government from Java Island. It is representative enough if this research only from java Island. If we take look to total local government, almost $50 a 5$ from Java Island

TABLE 1: Selected sample criteria.

\begin{tabular}{l|c|}
\hline Local Government in total & 435 \\
\hline deducted by local government not from java island & $(223)$ \\
\hline final sample & $\mathbf{2 1 2}$ \\
\hline
\end{tabular}

\subsection{Research model (operationalization of research concept)}

Measurement from various literature by using regression equation, with main variable focus on bureaucracy reformation, by content analysis of website local government in Java Island to indicate bureaucracy reformation. Following is the equation to test the hypotheses of this research:

$$
E K P P D=\alpha 0+\beta_{1} R B+\beta_{2} I P M_{i t}+\varepsilon_{i t},
$$

where:

EKPPD : Kinerja Pemda dalam Score EKPPD

RB : Reformasi Birokrasi

IPM : Indeks Pembangunan Manusia (as control variable).

\subsection{Variable measurement}

Independent Variable EKPP: Score Published by Ministry of Internal Affair

Reformasi Birokrasi: By content analysis, implementation of Bureaucracy Reformation exist by 1 and o otherwise

IPM is indeks Pembangunan Manusia (Human development Index) published by BPS, in Pdf form and randomly output of data, so by hand collected input data manually in the table, in order to processed the collected data. 


\section{Result}

Table 2 describes maximum value oand minimum value of numeric and kategoric data, also show the mean and deviation standard from major variable and control variable. It shows that for EKPPD score relative in the same range, contrastly, for IPM.

TABLE 2: Descriptive statistics.

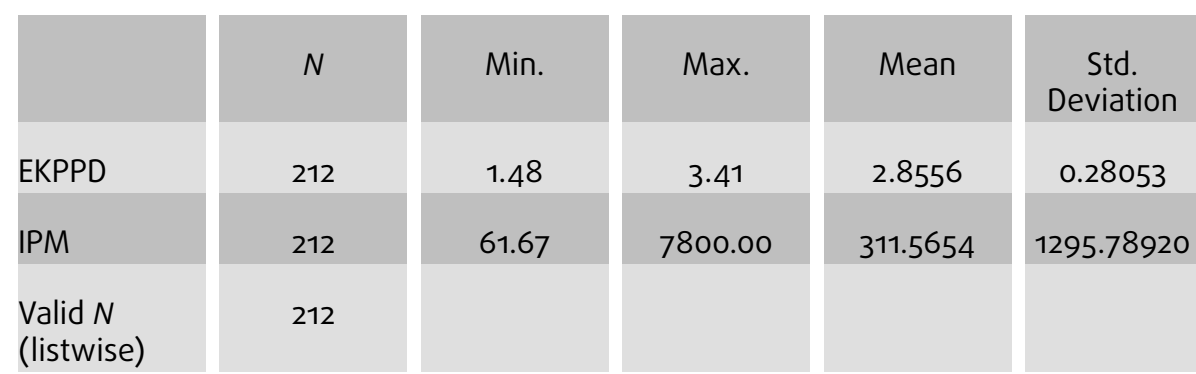

Table 3 describes maximum value oand minimum value of kategoric data, overall, mostly local governance support and have or exist for bureaucracy reformation.

TABLE 3: Bureaucracy Reformation (BR).

\begin{tabular}{|c|c|c|c|c|c|}
\hline & & Freq & Percent & Valid Percent & $\begin{array}{c}\text { Cumulative } \\
\text { Percent }\end{array}$ \\
\hline \multirow[t]{3}{*}{ Valid } & Tidak ada BR & 38 & 17.9 & 17.9 & 17.9 \\
\hline & ada BR & 174 & 82.1 & 82.1 & 100.0 \\
\hline & Total & 212 & 100.0 & 100.0 & \\
\hline
\end{tabular}

For testing hypotheses, regressed the equation and the result in the table 4.5, 4.6 and 4.7. The result showed that variable independent have explanatory power for about $0.14 \%$, it means that there some variables are not included in the research model. Surprisingly, Bureaucracy Reformation have negative effect at all for local government performance. We concluded that result did not support hypotheses. From prior research we know that this result consistent with result of research Martani (2013) findings that accessed for education will decreased local government performance.

Control variable, IPM did not research focus, results showed it has positive effect to local Government Performance, unfortunately the data of IPM cannot comply the classical assumption, it makes conclusion related to IPM very weak.

\section{cients $^{a}$}

Based on regression result from sub result of research, hypotheses building based on prior literature stated that one of the element of governance is democracy construct by reformation of bureaucracy. Measurement of reformation of bureaucracy, by content analysis hand collected we identified is there any support for reformation of 
bureaucracy, by search engine using keyword REFORMASI, BIROKRASI. This research has several limitations, such as, there are so many website of local government in the condition off line so cannot trace to indicate is there any support for reformation of bureaucracy. So, because of those limitations the result support did not research hypotheses. This is will be opportunity for future research.

Next limitations of research is, in-depth information about activity of bureaucracy of reformations in the websites of those local government in the large range. Limitations and weakness of this research will be opportunity for future research about topic public sector especially for measurement of variable, or get several variables that have effect to performance of local government performance evaluations.

Conclusions of this research, firstly, reformation bureaucracy has negative effect to local government performance. Secondly, event not fulfill classical assumptions, control variable has positive effect to local governmental performance evaluation. Research contributions are, firstly, extent research literature of topic of public sector of governmental. Secondly, beginning research of governmental and democracy. Thirdly, proxy for activity of bureaucracy reformations.

Implication of the research offered how to measure reformation bureaucracy is, mostly for regulator policy for local governmental, ministry of internal affair could be more focus for determinants for local government performance evaluation.

\section{References}

[1] Bangun A. (2009). Pengaruh partisipasi anggaran dan komitmen organissi terhadap kinerja SKPD Pemerintahan Kabupaten Kota. Skripsi. USU. Medan

[2] Fladimir Edwin Mbon. (2010). Pengaruh partisipasi penyusunan anggaran, kejelasan sasaran anggaran, dan akuntabilitas publik terhadap kinerja aparat PEMDA. Jurnal

[3] Fachruzzaman.(2010). Sistem Pengukuran Kinerja dan Penggunaan indormasi kinerja. Prosiding. SNA 2010

[4] Heny et al., (2010). Kinerja keuangan daerah, prosiding SNA

[5] Prihandini. (2011). Partisipasi dalam penyusunan anggaran. Jurnal

[6] Undang-Undang No. 32 (2004),. Evaluasi Kinerja Penyelenggaraan Pemerintahan Daerah

[7] Peraturan Pemerintah (PP) No. 3/2007 tentang Laporan Pertanggungjawaban Pemerintahan Daerah. (LPPD)

[8] Peraturan Pemerintah (PP No. 6/2008 tentang Evaluasi Kinerja dan Penyelenggaraan Pemerintah daerah (EKPPD)

[9] Sopanah, Wahyudi. (2010). Akuntabilitas sektor publik. SNA 
[10] http//www.WorldBank

[11] http//www.OECD

[12] Http//www.UNDP

[13] Situs resmi Pemda 